\title{
Socio Demographic Characteristics and Laboratory Evaluation of Children Admitted to Tertiary Care Hospital with Ascites
}

\author{
Keludeppa Talawar ${ }^{1}$ \\ ${ }^{1}$ Assistant Professor, Department of Paediatrics, SN Medical College, Bagalkot, Karnataka.
}

\section{Abstract}

Background: The most important consideration in a patient with a new onset of ascites is to perform a peritoneal tap and to ascertain the cause. A peritoneal tap is also indicated in a patient with known liver disease who presents with sudden clinical deterioration, worsening encephalopathy, or unexplained fever. A missed or delayed diagnosis of spontaneous bacterial peritonitis could potentially lead to sepsis and significant morbidity \& mortality. Prophylactic antibiotic therapy with a quinolone is often recommended. Subjects and Methods: All children with ascites were included in study irrespective of their primary diagnosis. Detailed history, complete physical examination \& routine investigations were done in all patients. Ascitic tap was done after taking written consent from the guardian with full aseptic precaution. Results: Diagnostic ascitic tap was done in 48 patients, off which it was clear in $70.83 \%$. In 8 patients the fluid was hazy in appearance suggestive of possibly infective origin either due to elevated protein or cells. One patient had milky appearance of ascetic fluid that suggests chylous nature of it. Conclusion: Proteinuria (33.3\%), Hypoalbuminemia (42.16\%), reversed AG ratio (34.3\%) \& hypercholesterolemia (37.2\%) were present all together in $33.3 \%$ (34) patients suggestive of Nephrotic syndrome.

Keywords: Socio Demographic Characteristics, Laboratory Evaluation, Ascites

Corresponding Author: Dr. Keludeppa Talawar, Assistant Professor, Department of Paediatrics, SN Medical College, Bagalkot, Karnataka.

Received: September 2019

Accepted: September 2019

\section{Introduction}

The most common complication of ascites is the development of spontaneous bacterial peritonitis. Performing repeated physical examinations and paying particular attention to abdominal tenderness may be the best way to become aware of the possible development of this complication.

Any patient with ascites and fever should have a paracentesis with bed side blood culture inoculation and cell count. Patients with a protein level of less than $1 \mathrm{gm} / \mathrm{dl}$ in ascitic fluid are at high risk for the development of spontaneous bacterial peritonitis. ${ }^{[1]}$

The most important consideration in a patient with a new onset of ascites is to perform a peritoneal tap and to ascertain the cause. A peritoneal tap is also indicated in a patient with known liver disease who presents with sudden clinical deterioration, worsening encephalopathy, or unexplained fever. A missed or delayed diagnosis of spontaneous bacterial peritonitis could potentially lead to sepsis and significant morbidity \& mortality. Prophylactic antibiotic therapy with a quinolone is often recommended. Complications of paracentesis include infection, electrolyte imbalances, bleeding and bowel perforation. Patients with long standing ascites are at risk of developing umbilical hernias. Large volume paracentesis often results in large intravascular fluid shifts. ${ }^{[2]}$

The prognosis for patients with ascites due to liver disease depends on the underlying disorder, the degree of reversibility of a disease process and the response to treatment.

All patients must be taught which complications are potentially fatal and the signs and symptoms that precede them. Abdominal distention and / of pain despite maximal diuretic therapy are common problem and patients must realize the importance of seeing a physician immediately. ${ }^{[3]}$ Elevation of the diaphragm, with or without pleural effusions (hepatic hydrothorax), is visible in the presence of massive ascites. More than $500 \mathrm{ml}$ of fluid is usually required for ascites to be diagnosed from abdominal films. Many nonspecific signs such as diffuse abdominal haziness, bulging of the flanks, indistinct psoas margin, poor definition of intra-abdominal organs, erect position density increase separation of small bowel loops containing small bowel may be present. ${ }^{[4]}$

In $80 \%$ of patients with ascites, the lateral liver edge is medially displaced from the thoraco-abdominal wall [Hellmer sign]. Obliteration of the hepatic angle is visible in $80 \%$ of healthy patients. In the pelvis, fluid accumulates in the recto-vesical fossa. The fluid produces symmetric densities on both sides of the bladder, which is termed a "dog's ear" or "Mickey Mouse" appearance. Medial displacement of the caecum and ascending colon and lateral 
displacement of the pro peritoneal fat line are present in more than $90 \%$ of patients with significant ascites. ${ }^{[5]}$

Real time sonography is the easiest and most sensitive technique for the detection of ascitic fluid. The smallest amount of fluid tend to collect in the Morrison's pouch and around the liver as a sonolucent band. With massive ascites, the small bowel loops have a characteristic polycyclic "Lollipop" or "arcuate" appearance because they are arrayed on either side of the vertically floating mesentery. ${ }^{[6]}$

Certain sonographic findings suggest that the ascites may be infected, inflammatory or malignant findings include coarse internal echoes (blood), fine internal echoes (chyle), multiple septa (tuberculous peritonitis, pseudomyxoma peritonei), loculation or atypical fluid distribution, matting or clumping of bowel loops, and thickening of interfaces between fluid and adjacent structures. In malignant ascites, the bowel loops do not float freely but may be tethered along the posterior abdominal wall plastered to the liver or other organs fluid collections.

In Cirrhosis of liver there is coarse parenchyma \& innumerable tiny hyper-echoic nodules \& innumerable tiny hypo-echoic nodules \& surface irregularity, regenerative nodules, distorted vascular channels, porto-systemic venous collaterals. ${ }^{[7]}$

Ascites is demonstrated well on CT scan images. Small amount of ascitic fluid localize in the right perihepatic space the posterior subhepatic space (Morrison's pouch) and the Douglas pouch. A number of CT features suggest neoplasia, Hepatic, adrenal, splenic or lymphnode lesions associated with masses arising from the gut, ovary, or pancreas are suggestive of malignant ascites. Patients with malignant ascites tend to have proportional fluid collections in the greater and lesser sacs, whereas, in patients with benign ascites, the fluid is observed primarily in the greater sac and not in the lesser omental bursae. ${ }^{[8]}$

\section{Subjects and Methods}

This was a prospective study of children of age group of infancy to 12 years.

Children admitted in pediatric wards of a teaching institute were taken for study.

All children with ascites were included in study irrespective of their primary diagnosis.

Detailed history, complete physical examination \& routine investigations were done in all patients. Ascitic tap was done after taking written consent from the guardian with full aseptic precaution.

\section{Procedure Of Ascitic Tapping}

1) Prerequisites - to see that urinary bladder is emptied before the procedure. Strict aseptic precaution is mandatory.

2) Position of the patient - patient is lying flat or propped up at a slight angle.

3) Sites of aspiration - Lower quadrant of abdomen, two finger breadth medial to the anterior superior iliac spine $\&$ few centimeters above the inguinal ligament.

4) Technique - selected site was infiltrated down to the parietal peritoneum with local xylocaine $1 \%$ anesthesia after testing for its hypersensitivity reaction prior to paracentesis. IV drip set needle 22 gauge (or venflon) was inserted using a $\mathrm{Z}$ track to prevent leakage of fluid. This was done by retracting (with one gloved hand) the skin caudally $2 \mathrm{~cm} \&$ then inserting the needle. The retracted skin was not released until the fluid flows or the needle had penetrated the peritoneum. When the needle was finally removed at the end of procedure, the skin resumes its original position \& seals the punctured site.

Samples were collected in plane test tube for examination \& various test performed.

\section{Results}

Table 1: Age distribution

\begin{tabular}{|l|l|l|l|}
\hline Years & Present study & Ganguly S et al & Runyon BA et al \\
\hline$<1$ & $6(5.88 \%)$ & $8 \%$ & $9.5 \%$ \\
\hline $1-4$ & $34(33.33 \%)$ & $35 \%$ & $37 \%$ \\
\hline $5-8$ & $34(33.33 \%)$ & $38.5 \%$ & $33.5 \%$ \\
\hline $9-12$ & $28(27.45 \%)$ & $18.5 \%$ & $20 \%$ \\
\hline
\end{tabular}

Maximum no. of patients were in the age group of 1-4 \& 5-8 years (33.33\% each). This observation is significant as the $p$ value is $<0.05$

Table 2: Sex distribution

\begin{tabular}{|l|l|l|l|}
\hline Sex & Present study & $\begin{array}{l}\text { Bhibhuti } \\
\text { das et al }\end{array}$ & Anju Aggarwal et al \\
\hline Male & $61(59.81 \%)$ & $70 \%$ & $60 \%$ \\
\hline Female & $41(40.19 \%)$ & $30 \%$ & $40 \%$ \\
\hline M:F & $1.49: 1$ & $2.33: 1$ & $1.5: 1$ \\
\hline
\end{tabular}

Male: Female ratio was 1.49:1. There is no significant difference between two sex as the $\mathrm{p}$ value is $>0.05$

Table 3: Socio-economic status

\begin{tabular}{|l|l|l|}
\hline Class & Present study & Runyon BA et al28 \\
\hline Upper & $7(6.86 \%)$ & $5 \%$ \\
\hline Upper middle & $19(18.63 \%)$ & $11 \%$ \\
\hline Lower middle & $20(19.60 \%)$ & $37 \%$ \\
\hline Upper lower & $25(24.51 \%)$ & $27 \%$ \\
\hline Lower & $31(30.39 \%)$ & $20 \%$ \\
\hline
\end{tabular}

Majority of patients belongs to lower (54.9\%) \& middle $(39.23 \%)$ as compared to higher class. There was no significant difference between lower \& middle class ( $\mathrm{p}$ value is $>0.05$ ).

The most common past illness was Nephrotic syndrome $(13.72 \%)$.

Past history of Chronic Liver Disease was present in $4.9 \%$ (5).

There was one patient who had past history of abdominal tuberculosis. 


\begin{tabular}{|c|c|c|c|c|}
\hline \multicolumn{5}{|c|}{ Table 4: Past History } \\
\hline \multicolumn{2}{|c|}{ Past history } & $\begin{array}{l}\text { present } \\
\text { study }\end{array}$ & $\begin{array}{l}\text { Kamlesh } \\
\text { Chopra et } \\
\text { al }^{[8]}\end{array}$ & $\begin{array}{l}\text { Runyon } \\
\text { BA et }\end{array}$ \\
\hline \multicolumn{2}{|l|}{ Ascites } & $8(7.84 \%)$ & $9 \%$ & $11 \%$ \\
\hline \multicolumn{2}{|l|}{ Jaundice } & $3(2.94 \%)$ & $35 \%$ & $7 \%$ \\
\hline \multirow{3}{*}{$\begin{array}{l}\text { Chronic } \\
\text { Liver } \\
\text { Disease- }\end{array}$} & $\begin{array}{l}\text { Wilson's } \\
\text { disease- } 2\end{array}$ & \multirow[t]{3}{*}{$5(4.90 \%)$} & \multirow[t]{3}{*}{$10 \%$} & \multirow[t]{3}{*}{$13 \%$} \\
\hline & $\begin{array}{l}\text { Gaucher's } \\
\text { disease-1 }\end{array}$ & & & \\
\hline & undiagnosed-2 & & & \\
\hline \multicolumn{2}{|c|}{ Upper GI bleeding } & $4(3.92 \%)$ & $26 \%$ & $21 \%$ \\
\hline \multirow[t]{2}{*}{$\begin{array}{l}\text { Nephrotic } \\
\text { syndrome }\end{array}$} & $\begin{array}{l}\text { Infrequent } \\
\text { relapse-10 }\end{array}$ & \multirow[t]{2}{*}{$\begin{array}{l}14 \\
(13.72 \%)\end{array}$} & \multirow[t]{2}{*}{-} & \multirow[t]{2}{*}{-} \\
\hline & $\begin{array}{l}\text { Frequent } \\
\text { relapse-4 }\end{array}$ & & & \\
\hline \multicolumn{2}{|c|}{ Tuberculosis } & $1(0.98 \%)$ & - & - \\
\hline
\end{tabular}

Table 5: Family history

\begin{tabular}{|l|l|l|}
\hline Family history & No. of patients & \% \\
\hline Tuberculosis & 3 & 2.94 \\
\hline Liver disease & 2 & 1.96 \\
\hline Renal disorder & 0 & 0 \\
\hline Cardiovascular disease & 0 & 0 \\
\hline TORCH to mother & 1 & 0.98 \\
\hline
\end{tabular}

Positive family history of Wilson's disease was present in elder sib of one child. One patient had family history of undiagnosed Chronic Liver Disease in far relative. Maternal history of CMV was present in one infant.

Table 6: Malnutrition
\begin{tabular}{|l|l|l|}
\hline Grading of malnutrition & Present study & Ganguly S et al59 \\
\hline Normal nutrition & $15(14.7 \%)$ & $10.44 \%$ \\
\hline Grade 1 & $53(51.96 \%)$ & $12.17 \%$ \\
\hline Grade 2 & $24(23.52 \%)$ & $33.04 \%$ \\
\hline Grade 3 & $5(4.9 \%)$ & $26.96 \%$ \\
\hline Grade 4 & $5(4.9 \%)$ & $17.39 \%$ \\
\hline
\end{tabular}

30 patients had normal weight on admission but as they lost edema, wt. also decreased significantly to show off their malnutrition.

Out of all patients, $51.96 \%$ were having grade I \& $23.52 \%$ $\&$ having grade II malnutrition. Severe malnutrition (grade III \& IV) was present in only $9.8 \%$. The observed difference is significant as the $\mathrm{p}$ value is $<0.05$.

Table 7: Ascites with organomegaly

\begin{tabular}{|l|l|l|l|}
\hline Signs & $\begin{array}{l}\text { Present } \\
\text { study }\end{array}$ & $\begin{array}{l}\text { Ganguly } \\
\text { S et al } \mathbf{I}^{[\mathbf{9 ]}}\end{array}$ & $\begin{array}{l}\text { Anju } \\
\text { Aggarwal et } \\
\mathbf{a l}^{[\mathbf{1 1 ]}}\end{array}$ \\
\hline Isolated ascites & $59(57.83 \%)$ & $46 \%$ & $41 \%$ \\
\hline $\begin{array}{l}\text { Ascites with } \\
\text { hepatomegaly }\end{array}$ & $27(26.47 \%)$ & $24.35 \%$ & $30 \%$ \\
\hline $\begin{array}{l}\text { Ascites with reduced } \\
\text { liver span }\end{array}$ & $6(5.88 \%)$ & $6.65 \%$ & $5 \%$ \\
\hline $\begin{array}{l}\text { Ascites with } \\
\text { Splenomegaly }\end{array}$ & $3(2.94 \%)$ & $7.35 \%$ & $8 \%$ \\
\hline $\begin{array}{l}\text { Ascites with spleno- } \\
\text { hepatomegaly }\end{array}$ & $7(6.86 \%)$ & $15.65 \%$ & $16 \%$ \\
\hline
\end{tabular}

Isolated ascites was detected in $57.83 \%$ of patients, where as accompanying hepatomegaly \& spleno-hepatomegaly were present in $26.47 \%$ \& $6.86 \%$ respectively.

6 patients had reduced liver span which is suggestive of progressive liver cell necrosis as seen in advance stage of cirrhosis of liver \& Fulminant hepatic failure.

3 patients had ascites, splenomegaly \& normal liver span. Extra hepatic portal hypertension usually manifest as ascites $\&$ splenomegaly with or without signs of upper GI bleeding.

Table 8: Ascitic fluid- examination

\begin{tabular}{|l|l|l|}
\hline Gross examination & Present study $(\mathbf{n}=\mathbf{4 8})$ & $\begin{array}{l}\text { Runyon BA et } \\
\text { al28 }\end{array}$ \\
\hline Clear & $34(70.83 \%)$ & $25 \%$ \\
\hline Hazy & $8(16.67 \%)$ & $25 \%$ \\
\hline Yellow & $5(10.4 \%)$ & $50 \%$ \\
\hline Milky & $1(2.08 \%)$ & 0 \\
\hline Reddish & 0 & 0 \\
\hline
\end{tabular}

Diagnostic ascitic tap was done in 48 patients, off which it was clear in $70.83 \%$. In 8 patients the fluid was hazy in appearance suggestive of possibly infective origin either due to elevated protein or cells. One patient had milky appearance of ascetic fluid that suggests chylous nature of it.

Table 9: Total cells

\begin{tabular}{|l|l|l|}
\hline Cells & Present study $(\mathbf{n = 4 8})$ & Runyon BA et al28 \\
\hline$<500$ & $40(83.33 \%)$ & $75 \%$ \\
\hline$>500^{*}$ & $8(16.67 \%)$ & $25 \%$ \\
\hline
\end{tabular}

* In all patients lymphocytes were predominant

In $83.33 \%$ ascitic fluid was transudative whereas in $16.67 \%$, it was exudative in nature. All those exudative fluid showed lymphocyte as a predominant cell in differential.

Table 10: Protein

\begin{tabular}{|l|l|l|}
\hline Protein & Present study $(\mathbf{n}=\mathbf{4 8})$ & Runyon BA et al28 \\
\hline$<2.5 \mathrm{gm}$ & $40(83.33 \%)$ & $75 \%$ \\
\hline$>2.5 \mathrm{gm}$ & $8(16.67 \%)$ & $25 \%$ \\
\hline
\end{tabular}

In $16.67 \%$ ascitic fluid protein was $>2.5 \mathrm{gm}$ indicate exudative nature.

Out of all, $37.2 \%$ of patients were having serological test positive for Dengue.

Proteinuria (33.3\%), Hypoalbuminemia (42.16\%), reversed AG ratio $(34.3 \%) \&$ hypercholesterolemia $(37.2 \%)$ were present all together in $33.3 \%$ (34) patients suggestive of Nephrotic syndrome.

Hypoproteinemia (9), reversed AG ratio (9), prolonged PT (9) \& hypercholesterolemia (4) were altogether present in $8.82 \%$ of patients attributed to Chronic Liver Disease.

KF ring on slit lamp examination, elevated urinary copper \& reduced serum ceruloplasmin were present in 2 patients, which is suggestive of Wilson's disease.

One patient who presented with ascites, portal hypertension $\&$ hepatomegaly had bone marrow aspiration suggestive of 
storage disorder- Gaucher's disease.

None of the patients from suspected liver disease had serological markers positive for viral hepatitis.

Liver biopsy was planned in 6 patients of undiagnosed Chronic Liver Disease. Three patients did not give consent, one patient absconded \&in one patient biopsy material was inadequate for study. Biopsy of one patient showed, PAS positive hepatocytes with diastase sensitive suggestive of Chronic Liver Disease.

Mantoux test was positive in $8(7.84 \%)$ patients, where as ascitic fluid ADA was elevated in 4 , to suggest abdominal tuberculosis.

One male neonate of 17 days having ascites \& clinical features of Congenital Rubella Syndrome (hepatomegaly, bilateral cataract, microcephaly \& ostium secundum ASD with large PDA) was positive of Rubella IgM. Another female neonate of 1 month old had ascites with splenohepatomegaly, was positive for CMV IgM. The 3 months male presented with ascites, anasarca $\&$ lab test positive for Nephrotic syndrome, was also positive for CMV IgG \&IgM. Two patients presented with ascites, hematuria \& hypertension with serological test for streptococcal infection positive suggestive of acute glomerulonephritis (PSGN). In one patient who presented with fever, ascites \& encephalitis was reactive for enteric fever.

Table 11: Special laboratory tests
\begin{tabular}{|l|l|l|}
\hline Tests & No. of patients & $\%$ \\
\hline S. Dengue IgM & 38 & 37.2 \\
\hline 24 hr urinary protein $>2 \mathrm{gm}$ & 34 & 33.3 \\
\hline Hypoalbuminemia $(<2.5 \mathrm{gm} / \mathrm{dl})$ & 43 & 42.16 \\
\hline Hypoproteinemia $(<3.5 \mathrm{gm} / \mathrm{dl})$ & 22 & 21.56 \\
\hline Reversed AG ratio & 43 & 42.16 \\
\hline Hypercholesterolemia( $>250 \mathrm{mg} / \mathrm{dl})$ & 38 & 37.20 \\
\hline Prolonged PT(>1.5 times) & 12 & 11.76 \\
\hline KF ring & 2 & 1.96 \\
\hline $\begin{array}{l}\text { Increased urinary copper } \\
\text { (>100mcg/day) }\end{array}$ & 2 & 1.96 \\
\hline Decreased ceruloplasmin & & \\
\hline $\begin{array}{l}\text { Bone marrow for storage disease- } \\
\text { Gaucher's disease }\end{array}$ & 2 & 1.96 \\
\hline HBs Ag reactive & 1 & 0.98 \\
\hline HCV & 0 & \\
\hline Positive Mantoux test $(>15 \mathrm{~mm})$ & 0 & 0 \\
\hline Ascitic fluid ADA positive & 8 & 0 \\
\hline S.TORCH & 4 & 7.84 \\
\hline S. widal & 3 & 3.90 \\
\hline ASO, CRP positive & 1 & 2.94 \\
\hline Decreased S. C3 levels & 2 & 0.98 \\
\hline & 2 & 1.96 \\
\hline
\end{tabular}

Out of all patients, USG was done in 80 patients that includes complicated Dengue Fever \& first attack Nephrotic syndrome. Uncomplicated Dengue \& Nephrotic syndrome relapse were excluded from study.

Out of these $27.5 \%$ of patients had only ascites (primary diagnosis was Nephrotic in most). $25 \%$ patients showed ascites \& hepatomegaly with normal echotexture (primary diagnosis was Dengue fever in most).

$16.25 \%$ (13) patients had altered hepatic echotexture of which $7.5 \%$ (6) had reduced liver size (primary diagnosis was Chronic Liver Disease).

$3.75 \%(3)$ patients had ascites, splenomegaly with normal liver size \& echotexture.

Table 12: Imaging study

\begin{tabular}{|c|c|c|c|}
\hline & USG findings & $\begin{array}{l}\text { No. of } \\
\text { patients } \\
(n=80)\end{array}$ & $\%$ \\
\hline \multirow[t]{4}{*}{ LIVER } & Ascites with normal liver & 22 & 27.5 \\
\hline & $\begin{array}{l}\text { Hepatomegaly with normal } \\
\text { echotexture }\end{array}$ & 20 & 25 \\
\hline & $\begin{array}{l}\text { Hepatomegaly with altered } \\
\text { echotexture }\end{array}$ & 7 & 8.75 \\
\hline & Shrunken liver & 6 & 7.5 \\
\hline \multirow[t]{2}{*}{ SPLEEN } & Ascites with Splenomegaly & 3 & 3.75 \\
\hline & Ascites with spleno-hepatomegaly & 7 & 8.75 \\
\hline \multirow{2}{*}{$\begin{array}{l}\text { Changes of } \\
\text { portal } \\
\text { hypertension* }\end{array}$} & Intrahepatic & 2 & 2.5 \\
\hline & Extra-hepatic & 3 & 3.75 \\
\hline \multirow{2}{*}{ Enlarged kidney } & With normal echotexture & 0 & 0 \\
\hline & With altered echotexture & 4 & 5.0 \\
\hline \multirow[t]{2}{*}{ Miscellaneous } & Mesenteric Lymphadenopathy & 4 & 5.0 \\
\hline & Bowel thickening & 2 & 2.5 \\
\hline
\end{tabular}

Lower in 1728 was the first to produce ascites experimentally, by ligating the thoracic segment of inferior vena cava. Bright in 1827 attributed the development of dropsical effusion in liver disease to obstruct the circulation through the branches of venaporta. Starling in $1895-96$ propounded the view that interchange of fluid between capillaries and tissue spaces depends in the resultant of hydrostatic and osmotic forces inside and outside the vessel. Herrick in 1907 aroused a suspicion that ascites could be due to progressive intra-hepatic fibrotic obstruction of portal vascular bed.

Hypoproteinemia came to be considered a causative factor for ascites in cirrhotic patients in 1907 by Gilibert, Chiary and Grent. Filinky observed in 1922 that not only Hypoproteinemia but reduction in albumen fraction is responsible for ascites formation.

Recently, investigators have been interested in hepatic lymph drainage as a factor in causation of ascites. Studies in this direction are made by Baggenstoss, Bopper and schaffer.

Ganguly et al,,${ }^{[9]}$ \& Runyon BA et al, ${ }^{[10]}$ studies showed that maximum no. of patients were in the age group of 1-8 years. Anju Aggarwal et al \& Kamlesh chopra et al showed mean age was 6 years $\& 7 \pm 0.5$ years respectively. ${ }^{[11,12]}$

High incidence in this age may be related to frequent 
occurrence of Nephrotic syndrome in this age group.

Bhibhuti das et al reported M:F of 2.33:1 \& Anju Aggarwal et al reported 1.5:1. ${ }^{[11,13]}$

Ganguly $\mathrm{S}$ et al \& Francesco Saleno et al showed M:F ratio of 1:0.85\& 1.3:1 respectively. ${ }^{[9,14]}$

Slightly higher preponderance of male could be due to preference to male child for health access \& hospitalization. Runyon BA et al, ${ }^{[10]}$ reported that maximum patients were of lower middle class (37\%) followed by upper lower(27\%).

Only $6.86 \%$ of patients were of upper class. There is significant difference between upper \& middle ( $\mathrm{p}$ value is $<0.05$ ) as well between upper \& lower (p value is $<0.05$ ). It may be due to more poor class patients comes to the public hospitals as compared to higher class, who prefer private nursing homes.

Kamlesh Chopra et al, ${ }^{[12]}$ showed that most common past history was Jaundice (35\%) followed by upper GI bleeding $(26 \%)$.

Runyon $\mathrm{BA}$ et al ${ }^{[10]}$ reported that most common past history was upper GI bleeding $(21 \%)$

Ganguly $\mathrm{S}$ et $\mathrm{al},{ }^{[9]}$ reported that $33.04 \%$ of patients had grade II malnutrition \& $26.96 \%$ had grade III malnutrition.

This suggests that there was no association between ascites \& poor nutrition.

Ganguly $\mathrm{S}$ et al, ${ }^{[9]}$ showed that isolated ascites was present in $46 \%$ of patients Ascites with hepatomegaly was present in $24.35 \%$.

Anju Aggarwal et al, ${ }^{[11]}$ reported, isolated ascites in $41 \%$ \& ascites with hepatomegaly in $30 \%$.

\section{Conclusion}

- Maximum no. of children were in the age group of 1-4 \& 5-8 years (33.3\% each).High incidence in these age might be related to frequent occurrence of Nephrotic syndrome in this age.

- Male: Female ratio is $1.49: 1$. There is no significant sex difference. Slightly higher male ratio may be due to preference to male children for hospitalization \& treatment.

- Majority of patients were of lower \& middle class. Patients from higher class were significantly less. This difference could be due to their preference for private nursing home as compared to public hospital.

\section{References}

1. Kevin Moore. Cirrhosis,Portal Hypertension, and ascites.Chap14.21.2 Oxford Text Book of Medicine.Eds David A Warrel. 4Edi Pg 733-741

2. Rocco VK et al.Cirrhotic ascites:Pathophysiology Diagnosis and Management. Ann Intern Med 1986;105:573-583

3. Floras JS, Legault L, Morali GA, Hara K, Blendis LM. Increased sympathetic outflow in cirrhosis and ascites: direct evidence from intraneural recordings. Ann Intern Med 1991; 114:373-380

4. Bichet DJ, Van Putten VJ, Schrier RW. Potential role of increased sympathetic activity in impaired sodium and water excretion in cirrhosis N Engl J Med 1982;307:1552-1557

5. Dudley FJ. Pathophysiology of ascites formation.Gastroenterology clin North Am 1992:21:215-235

6. Mauer, K., and Manzione, N. C Usefulness of the serum-ascites albumin gradient in separating transudative from exudative ascites: Another look. Dig. Dis. Sci. 33:1208, 1988

7. Cattau, E. 1., Benjamin, S. B., Knuff, T E., et al. The accuracy of the physical exam in the diagnosis of suspected ascites. JAMA 247: 1164, 1982

8. Hoefs, J. C. Increase in ascites WBC and protein concentrations during diuresis in patients with chronic liver disease. Hepatology 1:249, 1981.

9. Basu S, Ganguly S, Chandra PK: Clinical profile \& outcome of Ascites in Children ; Singapore Med J 2007; 48(10): 900

10. Runyon BA, Montano AA, Alkriviadis EA et al: The serum ascetic albumin gradient in the differential diagnosis of Ascites is superior to the exudates / transudate concept. Ann. Intern. Med. 1992; 117:215.

11. Anju Aggrawal, Jagdish Chandra, S. Aneja, AK Patwari, AK Dutta: Indian pediatrics $1998 ; 35 ; 727-32$

12. Basu S, Ganguly S, Chandra PK: Clinical profile \& outcome of Ascites in Children ; Singapore Med J 2007; 48(10): 900

13. Burroughs, A. K. Portal hypertension and variceal bleeding. Curro Opin. Gastroenterol. 8:388, 1992.

14. Floras JS, Legault L, Morali GA, Hara K, Blendis LM. Increased sympathetic outflow in cirrhosis and ascites: direct evidence from intraneural recordings. Ann Intern Med 1991; 114:373-380

Copyright: () the author(s), 2019. It is an open-access article distributed under the terms of the Creative Commons Attribution License (CC BY 4.0), which permits authors to retain ownership of the copyright for their content, and allow anyone to download, reuse, reprint, modify, distribute and/or copy the content as long as the original authors and source are cited.

How to cite this article: Talawar K. Socio Demographic Characteristics and Laboratory Evaluation of Children Admitted to Tertiary Care Hospital with Ascites. Asian J. Clin. Pediatr. Neonatol.2019;7(3):01-05.

DOI: dx.doi.org/10.21276/ajcpn.2019.7.3.1

Source of Support: Nil, Conflict of Interest: None declared. 